\title{
Rancang Bangun Media Moblie Learning Mata KuliahTeknologi Multimedia Dan Internet
}

\author{
Lativa Mursida*, Resmi Darni**, Ika Parma Dewi*** \\ *,**,*** Dosen Jurusan Teknik Elektronika, Fakultas Teknik, Universitas Negeri Padang \\ Jl. Prof.Hamka-Kampus UNP-Air Tawar Padang \\ e-mail: mlativa@ft.unp.ac.id, resmidarni@ft.unp.ac.id,ika_parma@ft.unp.ac.id
}

\begin{abstract}
Projections of modern technology as one of the implementations of the industrial revolution 4.0. in the world of education, it can be used as a supporter of the concept of learning, thinking, and developing creative and innovative innovations from students, to make the Pencerah become the Golden Indonesia Generation 2045 who is superior and able to compete at the global level. The current situation in the midst of the Covid-19 outbreak, Industrial Revolution Education 4.0 adapts the new curriculum. The curriculum must be able to open a window to the world through digital information, for example: utilizing a smartphone / android in the midst of the Covid-19 outbreak. Educators with a lot of exploring learning techniques and lots of references will be able to implement learning activities effectively even though they are currently in the midst of Covid-19, but all of this is not free from challenges in its implementation, especially educators. Making mobile learning media applications aims to produce learning media that makes it easier for students to learn multimedia and internet courses wherever they are. The development of this application uses the Prototyping development method with Android-based Java programming with Android Studio application software (version 3.3) with Gradle 4.4. This research produces an Android-based mobile learning media application, the features in this interactive module application are RPS, learning materials, videos, and exercises that are in accordance with the Electronic Engineering curriculum learning material, Faculty of Engineering, UNP.
\end{abstract}

\section{Keyword: Media, mobile learning, mata kuliah multimedia dan internet}

\section{Introduction}

Dosen adalah pendidik profesional dan ilmuwan dengan tugas utama mentransformasikan, mengembangkan, dan menyebarluaskan ilmu pengetahuan, teknologi, dan seni melalui pendidikan, penelitian, dan pengabdian kepada masyarakat [1]. Pengertian tersebut memberikan petunjuk kepada kita bahwa dosen sebagai pendidik profesional yang cakupan interaksi dengan peserta didik lebih luas dan dalam. Tidak hanya sekedar menyampaikan ilmu pengetahuan saja, namun pendidik profesional lebih menekankan pada proses perubahan, peningkatan, pengambangan, dan penguatan moral peserta didik. Dunia pada awal tahun 2020 harus menghadapi pandemik virus corona (COVID-19) yang menyerang sistem pernafasan manusia. Pilek, flu, mulai batuk, demam, dan/atau gangguan hidung merupakan gejala virus corona yang akhirnya berdampak bisa membunuh pengidapnya. Infeksi virus corona menyebar sangat sederhana dan cepat yaitu melalui sentuhan dan udara. Dalam dunia pendidikan di Indonesia, berjabat tangan, mencium tangan guru atau dosen, berkomunikasi secara langsung dengan jarak dekat adalah contoh sederhana penyebaran infeksi virus corona yang biasa dilakukan orang Indonesia

Aturan dan kebijakan dikeluarkan oleh pemerintah untuk mengantisipasi dan memotong rantai penyebaran ini. Larangan berkerumun dan melakukan kegiatan di luar rumah merupakan salah satu kebijakan pemerintah dalam menyikapi bahaya virus corona yang penyebarannya cepat tersebut. Membatasi aktifitas keluar rumah, kegiatan sekolah/universitas dirumahkan, bekerja dari rumah (work from home), bahkan kegiatan beribadah pun dirumahkan merupakan beberapa kebijakan yang diberikan oleh pemerintah [2]. Lembaga penyelenggara pendidikan (universitas) memberikan instruksi untuk melakukan belajar di rumah selama 14 hari dan masih bisa bertambah sesuai perkembangan pandemic virus corona berdasarkan kebijakan dari pemerintah. Kegiatan belajar mengajar jarak jauh menggunakan pembelajaran virtual atau penugasan sesuai materi dan mata kuliah baik teori dan praktek di rumah tetap dalam kendali pendidik (dosen).

Proyeksi teknologi modern sebagai salah satu pelaksanaan revolusi industri 4.0. dalam dunia pendidikan dapat dimanfaatkan sebagai pendukung konsep belajar, berpikir, serta mengembangkan inovasi kreatif dan inovatif dari mahasiswa, untuk mencetak Sang Pencerah menjadi Generasi Indonesia Emas 2045 yang unggul dan mampu bersaing pada tataran global. Situasi saat ini di tengah wabah Covid-19, Pendidikan Revolusi Industri 4.0 menyesuaikan kurikulum baru. Kurikulum harus mampu membuka jendela dunia melalui informasi digital, contoh: memanfaatkan smartphonelandroid di tengah wabah Covid-19. Pendidik dengan banyak menggali teknik pembelajaran dan banyak referensi akan mampu mengimplementasikan aktivitas belajar dengan efektif meskipun saat ini sedang di tengah Covid-19, namun semua ini tidak luput 
dari tantangan dalam pelaksanaannya, khususnya para guru. Pembelajaran merupakan suatu kegiatan yang melibatkan seseorang dalam upaya memperoleh pengetahuan, keterampilan, dan nilai-nilai positif dengan memanfaatkan berbagai sumber untuk belajar. Pembelajaran dapat melibatkan dua pihak yaitu siswa sebagai pembelajaran dan guru sebagai fasilitator. Yang terpenting dalam kegiatan pembelajaran adalah terjadinya proses belajar.[3]

Identitas guru yang efektif dalam mengajar, yaitu: (1) sanggup memncari strategi yang dipakai sehingga memungkinkan murid dapat belajar dengan baik; (2) Mempermudah murid memelajari sesuatu yang berguna seperti fakta, keterampilan, nilai, konsep, serta bagaiman hidup serasi dengan sesama; (3) Guru mempunyai keahlian yang profesional dan mampu mengenjawantahkan keterampilannya secara konsisten, bukan atas dasar seenaknya; (4) Keahlian tersebut diakui oleh mereka yang berkompeten, seperti guru, pelatih guru, pengawas sekolah, tutor, dan guru pemandu mata pelajaran atau bahkan murid-murid sendiri [4]. Pendidikan adalah sesuatu aktivitas yang mengaitkan seseorang dalam upaya memperoleh pengetahuan, keterampilan, dan nilai-nilai positif dengan memanfaatkan berbagai sumber untuk belajar. Pembelajaran dapat melibatkan dua pihak yaitu siswa sebagai pembelajaran dan guru sebagai fasilitator. Yang terpenting dalam kegiatan pembelajaran adalah terjadinya proses belajar.[4] Pelaksanaan PBM yang dilakukan pada matakuliah pratikum multimedia dan internet/TMI juga belum maksimal, Pada mata kuliah praktek TMI pada masa pandemic ini hanya dengan elearning. Media yang digunakan oleh dosen dalam penyampaian materi pembelajaran berupa elearning dan ditugasi mengerjakan per jobsheet. Kondisi tersebut diatas diprediksi mempengaruhi hasil belajar mahasiswa yang diperoleh dari dosen matakuliah TMI yang dapat dilihat pada tabel 1 sebagai berikut ;

Tabel 1. Nilai pratikum mata kuliah multimedia dan internet TA. Januari-Juni 2019

\begin{tabular}{|c|c|c|}
\hline \multirow{2}{*}{ Nilai } & \multicolumn{2}{|c|}{ Mahasiswa } \\
\cline { 2 - 3 } & 201810650069 & 201810650070 \\
\hline A & 1 & 3 \\
\hline A- & 6 & 7 \\
\hline$<$ B+ - E & 9 & 6 \\
\hline Jumlah & 16 & 16 \\
\hline
\end{tabular}

Dari hasil nilai diatas masih $12.5 \%$ yang memiliki nilai A dari dua kelas tersebut. Peneliti observasi dilapangan pada umumnya mahasiswa memiliki smartphone berbasis android $90 \%$. Namun penggunaan smartphone berbasis android sebagian besar mahasiswa memanfaatkan android hanya untuk menghabiskan sebagian waktunya untuk memutar musik, video, mengakses facebook, instagram, whatsapp, dan bermain game di rumah. Pemanfaatan android belum dimanfaatkan oleh dosen untuk media pembelajaran. Tingkat portabilitasnya yang tinggi/kemampuan menampilkan gambar, audio, animasi, video, simulasi/evaluasi, memungkinkan android dijadikan media pembelajaran. Berdasarkan kenyataan maka perlu dicari alternatif untuk mengatasinya sehingga diharapkan meningkatkan minat dan prestasi belajar mahasiswa pada matakuliah pratikum TMI dengan melakukan inovasi dalam penggunaan media pembelajaran yang valid, praktis, efektif. Penggunaan media pembelajaran berbasis android bertujuan memberikan pengalaman yang lebih dibandingkan media yang lainnya, sebab pada saat media digunakan ada dua indera yang berperan secara bersamaan yaitu indera penglihatan/pendengaran. Penggunaan android dikalangan mahasiswa mudah dibawa, bisa digunakan saat sekarang ini, dan dapat belajar mandiri kapanpun dan dimanapun. Pelaksanaan Proses pembelajaran dengan menggunakan multimedia dapat menjadi lebih berorientasi pada tujuan [5]. Menurut hasil penelitian Dale's Cone of Experience bahwa $90 \%$ dari siswa akan berhasil dari apa yang mereka lakukan saat mereka melakukan tugas [6]. Aplikasi multimedia bisa menyajikan data yang dapat dilihat, didengar serta dicoba, sehingga multimedia sangatlah efektif untuk menjadi perlengkapan (tool) yang lengkap dalam proses pengajaran dan pembelajaran. Berdasarkan uraian diatas, Penulis akan melakukan penelitian dengan judul "Rancang bangun media mobile learning mata Kuliah teknologi multimedia dan internet" 


\section{Research Method}

Metode penelitian pada riset ini adalah metode SDLC (System Development Life Cycle) Prototype. Model prototype suatu pengembangan Rekayasa Perangkat Lunak (RPL) dimulai dari mengumpulkan kebutuhan terhadap perangkat lunak yang akan dibuat. Setelah itu dilanjutkan dengan pembuatan program prototype agar customer terbayang dengan yang diinginkan. Program ini umumnya menyediakan tampilan dengan simulasi alur perangkat lunak sehingga tampak seperti perangkat lunak yang sudah jadi. berikutnya program prototype ini dievaluasi oleh customer hingga ditemui spesifikasi yang sesuai dengan keinginan customer [7]. Rancang bangun aplikasi multimedia interaktif mobile learning berbasis android bisa dicoba dengan memakai bahasa pemograman Java dan IDE Android Studio (version 3.3) dengan Gradle 4.4. Pengolahan dan penyimpanan data pada rancang bangun aplikasi multimedia interaktif mobile learning interaktif berbasis android dapat dilakukan dengan menggunakan library SharePreference. Berikut adalah ilustrasi umum dari model prototype.

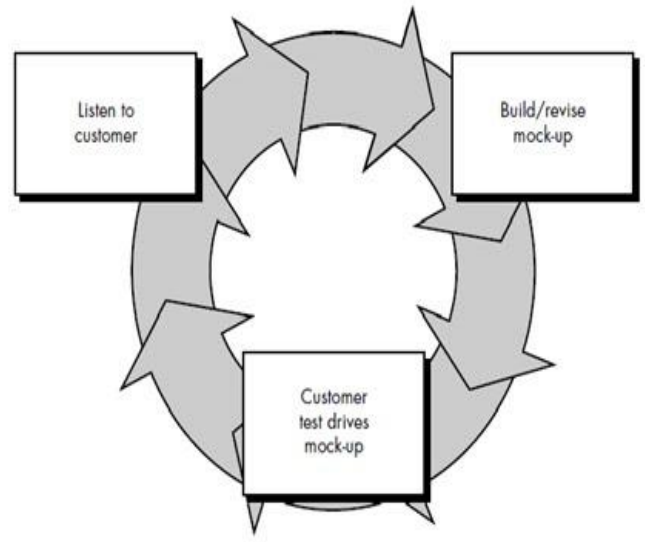

Gambar 1. Metode SDLC Prototype [6]

Gambar 2 adalah flowchart yang alur penelitian dari penelitian ini

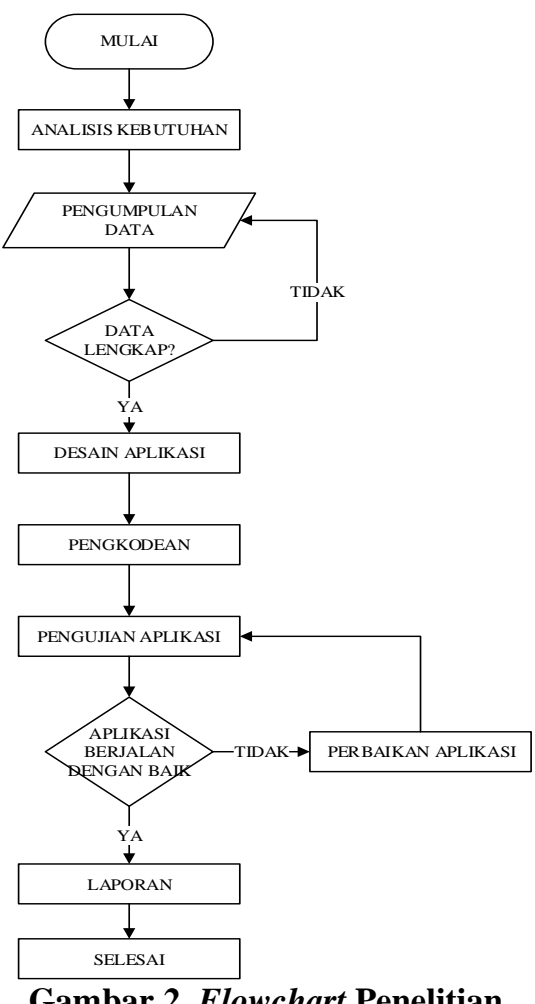

Gambar 2. Flowchart Penelitian 


\section{Result and Analysis}

Desain perancangan sistem aplikasi multimedia interaktif mobile learning mata kuliah multimedia dan internet menggunakan use case diagram, activity diagram dan class diagram.

\section{Use case Diagram}

Gambar 3. Mengambarkan use case diagram terdiri dari satu aktor yaitu mahasiswa. Mahasiswa adalah aktor yang berinteraksi dengan aplikasi. Mahasiswa berhubungan langsung dengan use case entri nama, melihat user guide, melihat menu silabus, melihat menu RPS, melihat menu materi, melihat menu video, menjawab kuis. Use case entri nama berelasi include dengan use case cek nama. Use case melihat user guide berelasi dengan use case cek kondisi. Use case melihat menu silabus, melihat menu RPS, melihat menu materi, melihat menu video, melihat kuis berelasi include dengan use case cek kunci. Use case cek nama, cek kondisi, cek kunci dan simpan nilai berelasikan extend terhadap use case simpan data.

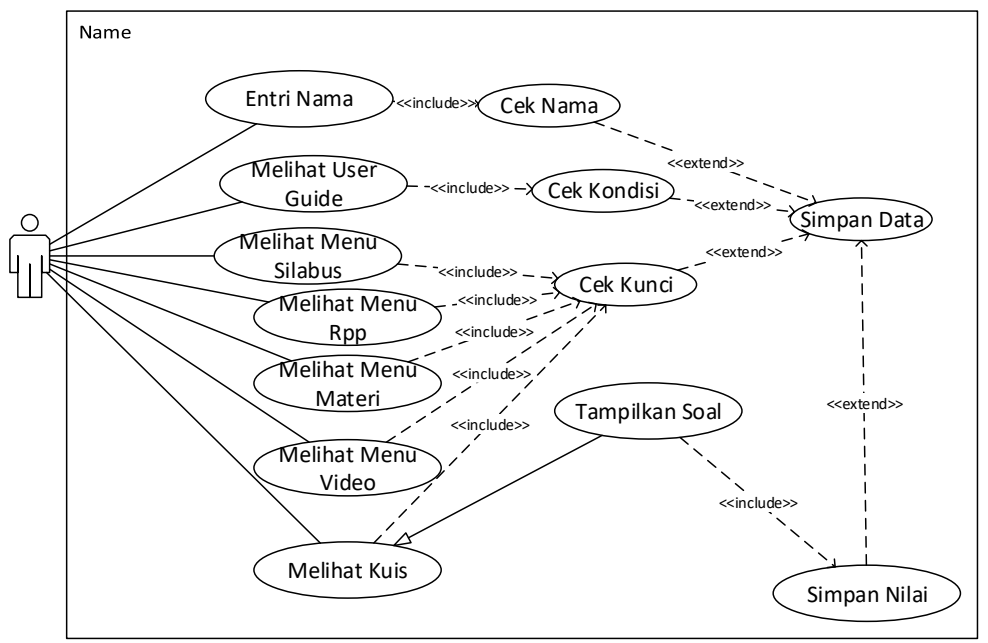

Gambar 3. Use case Diagram Aplikasi Multimedia Interaktif Mata kuliah multimedia dan internet

\section{Activity Diagram}

Gambar 4. Activity Diagram atau diagram aktivitas menggambarkan workflow (aliran kerja) atau aktivitas dari sebuah sistem atau proses bisnis. Activity diagram dari aplikasi multimedia interaktif mobile learning mata kuliah multimedia dan internet sebagai berikut :

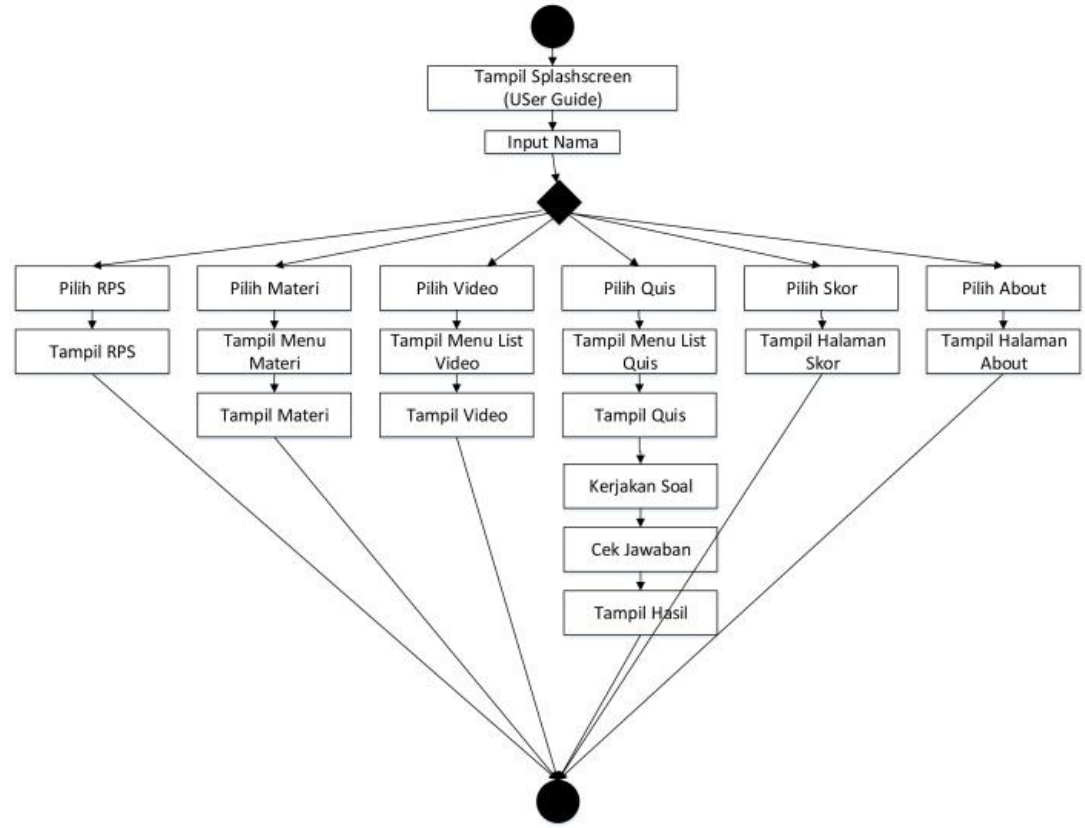

Gambar 4. Activity Diagram Aplikasi Multimedia Interaktif Mobile Learning Mata kuliah multimedia dan internet 
Hasil rancangan tampilan merupakan rancangan antarmuka aplikasi mobile learning mata kuliah teknologi multimedia dan internet yang telah dirancang. Aplikasi menampilkan program yang dirancang dengan memperhatikan aspek desain yang menarik dan user friendly (ramah terhadap pengguna) sehingga pengguna menjadi jelas dalam menggunakan aplikasi yang dibuat. Perancangan tampilan juga harus mempertimbangkan ukuran layar dan spesifikasi teknis smartphone kebanyakan calon pengguna yaitu mahasiswa.

Setelah sistem selesai dibuat dilakukan pengujian dengan dua cara yaitu wawancara dengan kuisoner dan pengujian terhadap sistem itu sendiri. Proses pembuatan dan pengujian pada emulator selesai maka program aplikasi akan diuji pada perangkat mobile sesungguhnya yaitu smart phone yang menggunakan sistem operasi Android yang ada di pasaran. Fungsionalitas yang ada pada program aplikasi akan dicoba dengan tujuan mengetahui apakah semua fungsi berjalan dengan baik atau tidak. Kuisioner dilakukan dengan tujuan untuk mengetahui penilaian oleh user tentang aplikasi penampil materi-materi mata kuliah TMI. Kuisioner dilakukan setelah aplikasi penampil materi-materi mata kuliah TMI telah selesai dibuat dan siap untuk diujikan. Pengujian dilakukan terhadap 32 orang mahasiswa yang mengampu mata kuliah TMI semester ganjil januari-Desember 2020 dengan menggunakan kuisioner yang berisi pernyataan-pernyataan sesuai dengan variabel yang akan diamati.

Tampilan rancangan inilah yang merealisasikan proses perancangan sistem pada tahap desain perancangan yaitu terjadinya interaksi antara pengguna dan aplikasi. Hasil rancangan tampilan dapat dijelaskan di dalam poin-poin berikut ini.

\section{1) Halaman Splash Screen}

Splashscreen adalah suatu halaman yang menampilkan logo dan ciri khas dari aplikasi. Durasi untuk menampilkan splash screen ini dirancang dengan durasi yang singkat.

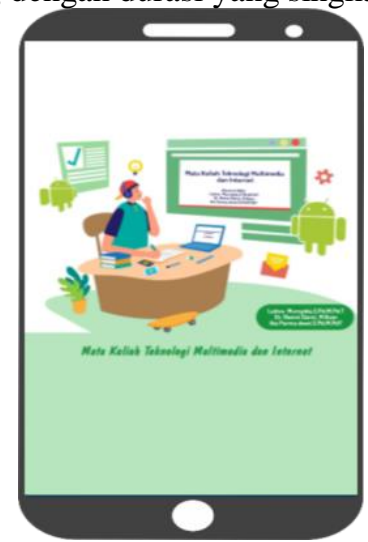

Gambar 5. Tampilan SplashScreen

\section{2) Halaman User Guide}

Dukungan onbording (user guide) pada aplikasi sangat penting untuk penggunaan pertama bagi pengguna. Halaman ini harus memuat tips penggunaan aplikasi. Halaman ini juga harus dirancang memiliki tombol lewati, sehingga pengguna memiliki kontrol dan pilihan . Berdasarkan dengan pernyataan tersebut halaman user guide yang telah dirancang juga hanya akan tampil untuk penggunaan pertama saja. Halaman ini juga memuat tip dan cara cara penggunaan aplikasi dalam bentuk tampilan slide. Pada setiap slide telah di desain memiliki sebuah tombol lewati. Tombol ini bertujuan untuk melewati slide yang di sediakan oleh sistem. Sehingga pengguna memiliki kontrol sepenuhnya. 


\section{3) Halaman User Screen}

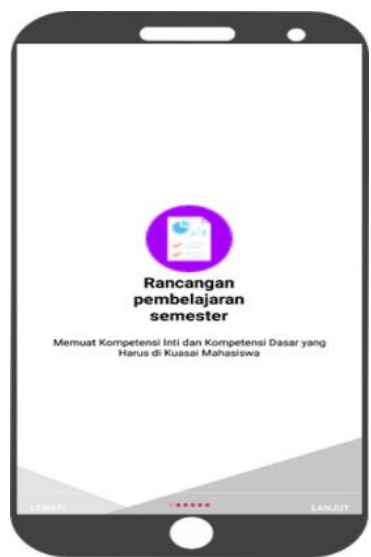

Pendaftaran identitas pengguna umumnya hanya meminta data yang penting saja [8]. Halaman ini telah dirancang dengan form pendaftaran nama saja dalam bentuk field text yang harus di isi oleh pengguna. Apabila pengguna mengisi dengan tidak benar sistem akan menampilkan pesan error. Setelah pengguna mengisi dengan benar sistem akan menyimpan dan menjalankan halaman berikutnya.

\section{4) Halaman Home}

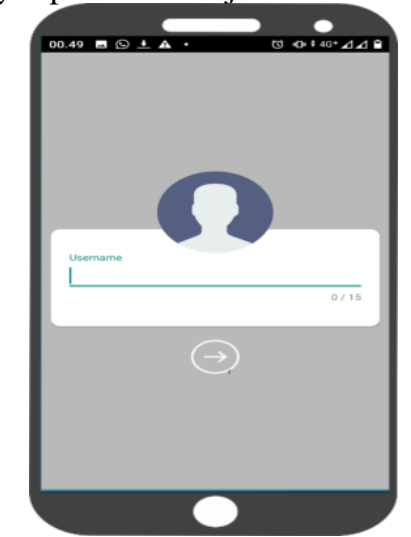

Halaman home screen aplikasi adalah tampilan halaman utama yang menampilkan tombol yang terdri dari tombol RPS (Rancangan Pembelajarn semester), materi, video, quis, skor dan about.

\section{5) Halaman RPS}

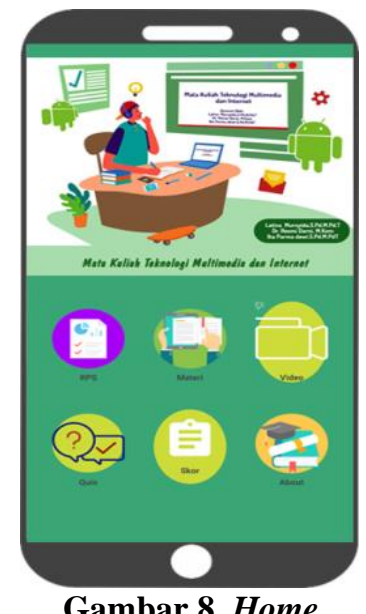

Halaman RPS (Rancangan Pembelajaran Semester ) yang berisikan tampilan silabus mata kuliah teknologi multimedi dan internet. Halaman ini berisikan rancangan pembelajaran selama satu semester. Halaman in 
dirancang memiliki tombol foating yang digunakan untukmendownload RPS yang tersedia di aplikasi. Pada halaman in juga terdapat tombol back untuk kembali ke halaman utama.

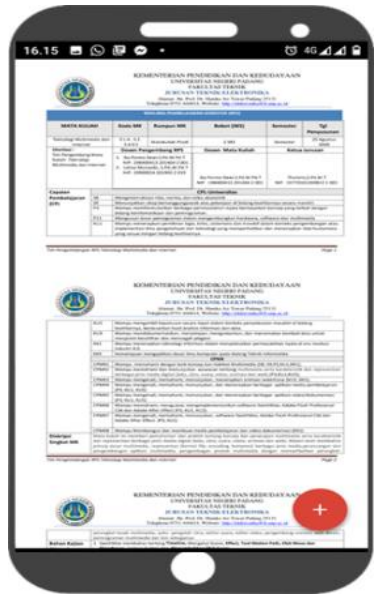

\section{6) Halaman Materi}

Gambar 92. Menu RPP

Halaman materi juga telah dirancang dengan model pembelajaran terstruktur. Halaman ini terdiri dari sepuluh pertemuan yang setiap menu nya terbagi tiga sub menu yaitu: menu materi, menu latiha, dn menu video.Pengguna aplikasi teknolog multimedia dan internet akan belajar lebih banyak ketika pelajaran dan kegiatan diperkenalkan dan tujuan pembelajaran ditentukan [9].

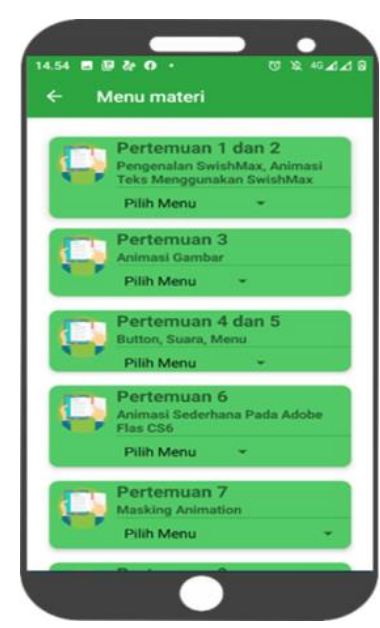

\section{Gambar 103. Menu Materi}

\section{7) Halaman Materi Pokok}

Halaman materi pokok adalah tampilan halaman yang menampilkan materi dan jobsheet, sehingga pada halaman ini lah pengguna dapat mempelajari materi teknologi multimedia dan internet.

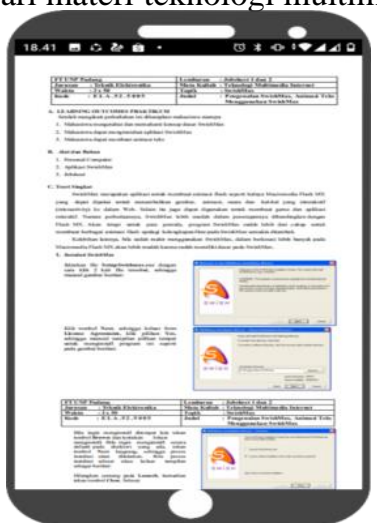

Gambar 11. Menu Materi Pokok 
Video memegang peranan penting dalam aplikasi teknologi multimedia dan internet untuk membuat pengguna menjadi lebih tertarik [9]. Halaman video telah dirancang dengan konten semenarik mungkin. Halaman yang berisi sepuluh menu yang setiap kontennya berisi video. Setiap video disajikan dalam bentuk animasi dan navigasi kontrol yang jelas.

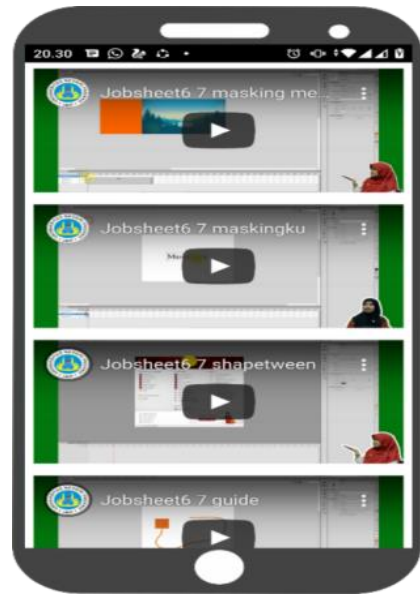

9) Halaman Kuis

Gambar 12. Tampilan Video

Halaman kuis adalah halaman yang menampilkan pilihan ganda, jawaban akan muncul di akhir pertanyaan.

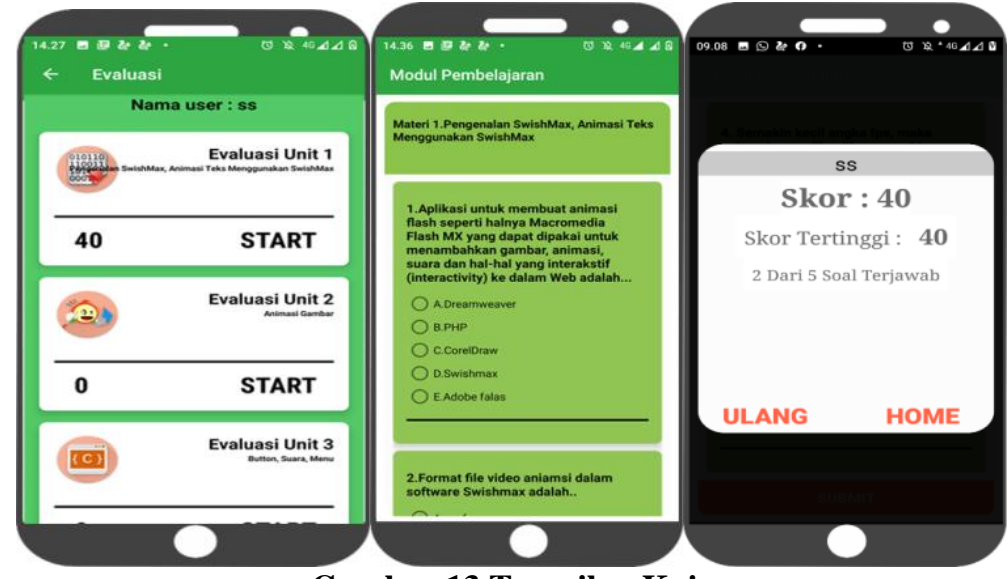

Gambar 13 Tampilan Kuis

10) Halaman Profil

Halaman profil adalah halaman yang menampilkan profil dari tim pengembang aplikasi. Dalam mengembang ini terdiri dari tiga orang dosen dari jurusan Pendidikan Informatika Fakultas Teknik Universitas Negeri Padang.

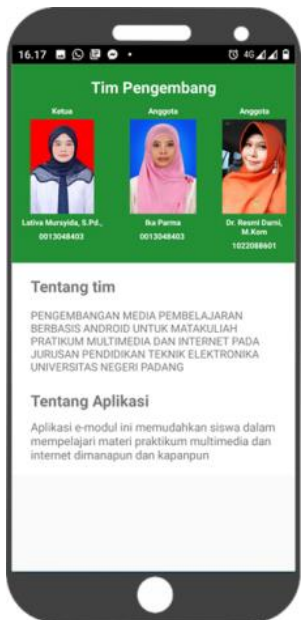

Gambar 14. Tampilan profil 


\section{1) Analisa Data Kuisioner}

Kuisioner diberikan ke mahasiswa dengan tujuan mengetahui penilaian user terhadap aplikasi mata kuliah TMI dan memahami cara pemasangan aplikasi multimedia interaktif mobile learning pada mata kuliah multimedia dan internet di smartphone melalui google Play Store yaitu https://play.google.com/store/apps/details?id=com.app.app_tmi. Aplikasi diunggah ke play store untuk memudahkan mahasiswa mengakses aplikasi mata kuliah TMI dan diujicoba ditujukan kepada 32 orang mahasiswa. Penilaian aplikasi baik dan buruknya dihasilkan dari hasil kuisioner tersebut

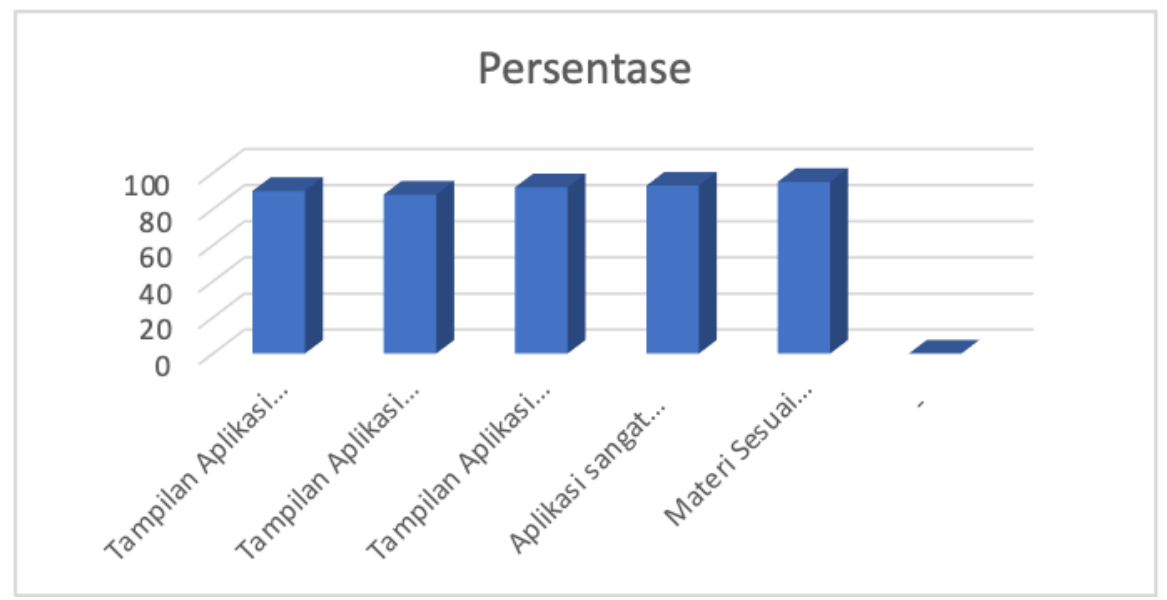

\section{Gambar 15. Grafik Hasil Kuisoner}

Pengujian media pembelajaran mata kuliah TMI semester ganjil januari-Desember 2020 dan melalui kuisioner yang dibagikan kepada 32 orang berdasarkan gambar 15, Semua jawaban yang diperoleh berbedabeda, tetapi sebagian besar menyatakan setuju. Untuk kuisioner point pertama Tampilan Aplikasi Mudah Dipahami perhitungan persentase interpretasi di peroleh $90 \%$. Poin kedua Tampilan Aplikasi Mudah Dioperasikan perhitungan persentase interpretasi terdapat $88 \%$. Untuk point ketiga Tampilan Aplikasi Efektif Tampilan perhitungan persentase interpretasi yaitu $92 \%$. Point ke empat tentang Aplikasi sangat Jelas tentang isi dan kebutuhan perhitungan persentase interpretasi yaitu $93 \%$. Dan point kelima tentang Materi Sesuai Kebutuhan mata kuliah TMI yaitu $95 \%$. Dalam perhitungan menghasilkan persentase interpretasi sebesar 91,6\%. Penerapan model mobile learning berbasis Android sangat mendukung berpusat pada mahasiswa dan mendorong mahasiswa untuk belajar mandiri dan berkolaborasi dengan teman sekelas. Belajar tidak hanya di a tempat atau ruangan tertentu, tetapi mereka dapat melakukannya di mana saja dan kapan saja. Android yang dimiliki mahasiswa tidak hanya digunakan untuk melihat situs yang kurang berguna tetapi dapat digunakan untuk belajar.

\section{Conclusion}

Berdasarkan penelitan yang telah dilakukan dapat diambil kesimpulan sebagai berikut:

1. Rancang bangun aplikasi multimedia interaktif mobile learning berbasis android dapat dibangun dengan menggunakan bahasa pemograman Java dan IDE Android Studio (version 3.3) dengan Gradle 4.4.

2. Pengolahan dan penyimpanan data pada penelitian ini dilakukan dengan menggunakan library SharePreference.

3. Aplikasi multimedia interaktif mobile learning pada mata kuliah multimedia dan internet di smartphone dapat diunduh di google Play Store (https://play.google.com/store/apps/details?id=com.app.app_tmi)

\section{References}

[1] Undang-Undang No 14 Tahun (2005), R. I. (n.d.). Undang-undang Guru dan Dosen. Produk Hukum. https://doi.org/http://dx.doi.org/10.1016/S0167-2991(08)63816-1

[2] Yunus, N. R., \& Rezki, A. (2020). Kebijakan Pemberlakuan Lock Down Sebagai Antisipasi Penyebaran Corona Virus Covid-19. SALAM: Jurnal Sosial Dan Budaya Syar-I. https://doi.org/10.15408/sjsbs.v7i3.15083

[3] Abidin, M. M., Purnama, B. E., \& Nugroho, G. K. (2013). Pembangunan Media Pembelajaran Teknik Komputer Jaringan Kelas X Semster Ganjil Pada Sekolah Menengah Kejuruan Taruna Bangsa Pati Berbasis Multimedia Interaktif. IJNS-Indonesian Journal on Networking and Security, 4(3).

[4] Marno \& Idris. (2010). Strategi dan Metode Pengajaran. Yogyakarta: Ar-Ruzz Media Group 
[5] Reddi, Usha V \& Sanjaya Mishra. (2015). Educational Multimedia A Handbook for TeacherDevelopers. New Delhi: Commonwealth Educational Media Centre for Asia 52.

[6] Dale's Cone of Experience. (1969). http://www.queensu.ca/teachingandlearni ng /modules/active/documents/Dales_Cone_of_Experience_summary.pdf. Di akses pada tanggal 17 April 2017.

[7] Rosa A.S \& M. Shalahuddin. (2015). Rekayasa Perangkat Lunak. Bandung: Informatika

[8] Griffiths, Stephen. (2015). Mobile App UX Principles. Google

[9] Munir. (2012). Multimedia Konsep \& Aplikasi dalam Pendidikan. Bandung: Alfabeta

[10] Rahmiati.(2020). The Effect of Mobile-Learning Models on Students' Learning Outcomes of Research Methodology Courses at the Cosmetology and Beauty Department. Proc-2020. Page 1-5 IEEE . DOI: 10.1109/ICVEE50212.2020.9243201 